\title{
MALAY, ENGLISH AND RELIGION: LANGUAGE MAINTENANCE IN MULTILINGUAL SINGAPORE
}

\author{
Mukhlis Abu Bakar \\ National Institute of Education, Nanyang Technological University \\ mukhlis.abubakar@nie.edu.sg
}

\begin{abstract}
The ideologies underlying Singapore's language-in-education policy drive home the message that students should feel some form of emotional connection to their mother tongue. At the same time, English is privileged leading many to index it with education, upward mobility, modernity and prestige. Singapore parents are cognisant of these ideologies and play an important role in mediating their children's affiliation to the respective languages and influencing their language use patterns. This study seeks to obtain a sense of how parents of 8-year old children struggle with competing ideologies when enrolling their children in one of two Islamic religious education programmes: English-medium Kids aL.I.V.E. and Malay-medium mosque madrasah. Parents of 35 children from the two programmes reported on their use of Malay and English, and their children's proficiency in, and use of, the two languages. Their reports suggest that the children were equally proficient in both languages but English was their dominant language. Parents were highly supportive of the language medium of the respective programmes, but irrespective of which language they supported, many were strongly affiliated to Malay citing reasons that mirror the state ideology that calls on its citizens to stay rooted in their ethnic heritage through their mother tongue.
\end{abstract}

Keywords: Islamic religious education, bilingualism, medium of instruction, language maintenance, language ideology

\section{Introduction}

Singapore's language-in-education policy is officially bilingual: from the start of schooling, English is the medium of all subject-area instruction, but students are also required to study their official mother tongue (MT henceforth) as a single subject (Mandarin for the Chinese, Malay for the Malays, Tamil for the Indians). ${ }^{1}$ English is intended to serve the mainly instrumental function of providing access to scientific and technological knowledge while the MTs provide Singaporeans with a sense of ethnic identity. The premium placed on English has resulted in a significant number of Singapore children starting to come from homes where English (rather than the MT) is the spoken language (Vaish, 2008). The Malay community is not spared of this 
phenomenon despite being more successful than the other communities in keeping the MT as the dominant language (Stroud, 2007). English as a home language among Malay Singaporeans rose from $6.1 \%$ in 1990 to $7.9 \%$ in 2000, and more than doubled to $17.0 \%$ in 2010 (Singapore Department of Statistics, 2001, 2011). The family as the stronghold of the Malay language in Singapore (Cavallaro \& Serwe, 2010) thus seems to be under threat.

The Malays are a minority community in Singapore constituting $13.4 \%$ of the resident population of 3.8 million (Singapore Department of Statistics, 2011). Almost all Malays profess Islam as their religion. For a long time, Malay (other than Arabic) mediated their learning of Islam (Sa'eda Buang, 2010) with religious classes and Friday sermons all delivered in the language. However, in recent years, to cater to the increasing number of non-Malay Muslim foreign workers and professionals and their families as well as the increasing preference for English among Malay children, mosques have begun giving sermons in English and more religious classes are being conducted in the language. Religion which hitherto is an important domain for Malay language maintenance in Singapore (Chong \& Seilhamer, 2014; Stroud, 2007) no longer appears to be a safe haven for the language.

Two studies at the interface of language and religion offer two contrasting results. A survey by Norhaida Aman (2009) shows that $67 \%$ of her 205 ten-year-old Malay respondents used mainly Malay in learning about Islam and in prayer. In contrast, a survey by Rohan Nizam Basheer (2008) shows that only $36 \%$ of his 108 respondents aged 12-17 years enrolled in an English-medium Islamic religious education programme preferred to be taught in Malay; the majority (64\%) preferred English. This contradictory set of findings sets the stage for the present study which elicited responses from parents of children enrolled in English- and Malay-medium Islamic religious education classes. The study aims to ascertain in more detail the extent of preference for Malay and English as the choice of language for the learning of Islam and the ideologies that underpin those preferences. The paper will also explore home language use, and children's language proficiencies. Overall, these would give an indication of the position of religion as the domain for Malay language maintenance.

\section{Malay Language in the Singapore Context}

Language shift and language maintenance of the MTs - Chinese, Malay and Tamil have been well documented. Some appear as detailed studies of census data (Kuo, 1980; Kuo \& Jernudd, 2003) while others as detailed analyses of the language shift of particular ethnic groups such as the Chinese (Kwan-Terry, 2000; Xu, Cheng, \& Chen, 1988), Indians (Schiffman, 2002), and Malays (Cavallaro \& Serwe, 2010; Norhaida Aman, 2009; Roksana Bibi Abdullah, 2003). Some salient points pertaining to the Malay language are discussed here.

Section 152 of the Singapore Constitution recognises the Malays as Singapore's indigenous community and Malay as the national language. It used to be that speaking Malay in Singapore was never a purely ethnic affair because Malay also functioned as the language of wider communication (Kuo, 1980). Today, however, with the English-plus-MT policy in place and the learning of the national language 
being squeezed out of the curriculum, most non-Malays do not speak the language. In fact, many Singaporeans are not aware that Malay is the national language, believing that there are only four official languages (Ong, 2006). After Singapore's independence in 1965, Malay lost its traditional role and gradually evolved into a more exclusive ethnic language spoken only by Malays (Kuo, 1980).

Within the Malay community, Malay is losing ground, albeit slowly, as the home language - from $92 \%$ in 2000 to $83 \%$ in 2010, with the $9 \%$ that dropped Malay adopting English instead (Singapore Department of Statistics, 2011). Census 2010 reports that the youngest age group (5-14 years old) showed the highest increase in the use of English as the home language - from 9.4\% in 2000 to $25.8 \%$ in 2010. In contrast, those aged 55 and above only saw an increase from 1.7 to $5.5 \%$. Records from the Ministry of Education (MOE) show that more Primary 1 Malay pupils are coming from English-speaking homes - 13\% in 1991 to 37\% in 2010 (Ministry of Education, 2010). An MOE survey on Primary 6 students in 2010 shows a more nuanced picture of language use. For Malay language students, the use of Malay at home was still prevalent (50\%) with only $17 \%$ using predominantly English. The remaining third used both English and Malay at home. Future census reports are likely to show further increases in the use of English (as a primary language or in concert with Malay) across all age groups and in domains such as religion where Malay used to dominate.

Amidst the shift to English, Malay is still well-maintained by older members of the community (Cavallaro \& Serwe, 2010). They play an important role in helping the young keep a close connection with the language. It is useful to note that the greater use of English among the young need not imply a diminished sense of inheritance and affiliation towards Malay. A study by Chong and Seilhamer (2014) shows that among the young and highly educated segment of the Malay population, there was a strong sense of inheritance and affiliation with Malay, even as English became an increasingly integral part of their lives. Much of this was attributed to the crucial role played by parents and grandparents in cultivating in these young educated Malays a sense of language inheritance for Malay which in turn helped develop an affiliation for the language.

\section{Language and Ideology}

The language shift demonstrates the importance of status and power between languages in multilingual societies. Scholars have used the term "dominant language" to acknowledge the power particular languages has on other languages. This term makes explicit the socio-historical processes - how certain languages achieve dominance over other languages - which are often hidden through the use of terms that appear neutral such as "standard" language (Grillo, 1989). In Singapore, English is the dominant language and is emphasised from the beginning of formal schooling. It stems from the belief propounded by Lee Kuan Yew, main architect of the language policy, that children will learn English better the earlier they start learning the language, and that the path to academic success in English is to use English more. Urging Malays to increase their use of English in order to improve the educational achievement of the children, Lee remarked that: 
parents have to decide on the trade-off between the convenience of speaking Malay or the mother tongue at home with their children at the cost of EL1 (English studied at a "first language" or L1 level). If they want their children to do well in EL1, their children must also, besides Malay, speak in English at home. If parents cannot speak English, then their children should use English with brothers, sisters and neighbours ("Education is the Road to Success," 1982, p. 16).

Lee made clear the separation of Malay and English. He did not consider the development of Malay usually spoken at home as helpful in gaining proficiency in English, that proficiency in one language could be helpful in gaining proficiency in another. There is growing evidence for this. Research has shown that L2 (English) is learned more easily from a solid base in one's L1 (MT) in the case of reading and writing skills and vocabulary (Cummins, 1984; Dixon, 2011; Lanauze \& Snow, 1989). Dixon's (2011) study on Singaporean kindergarten children's English vocabulary knowledge shows that children with higher MT vocabulary tended to have a higher English vocabulary. In a study in Miami, a city which maintains a high-status, politically strong Spanish-speaking community within the larger monolingual Englishspeaking context of the United States, Oller and Eilers (2002) compared two models of education: (a) English immersion programmes where children studied Spanish as a subject, much like Singaporean children study MT as a single subject, and (b) twoway Spanish-English bilingual programmes where children studied subject-area content through both English and Spanish. In both models, children perform at about the same high level in English, but the two-way programme produces much superior results in Spanish.

Lee's position appears to be based on the belief that individuals are expected to maintain cognitive separation of the linguistic systems, and that "properly" bilingual individuals are those in complete control of compartmentalised sets of monolingual proficiencies, such as English and Malay (Wee, 2011). This is in contrast to the idea that the general cognitive skills which underpin language use operate from a common central function, and that the ability to make sense of print transfers readily even when scripts are different (Cummins, 1991). It is thus not surprising that Malay, as is the case with the other smaller official languages, is a subject to be learnt, rather than a medium for subject-area instruction, in a system that aims to develop English-MT bilingualism, consistent with Lee's beliefs.

The above are instantiations of language ideology at work. Language ideologies are conceptualisations about languages, speakers, and discursive practices. They are pervaded with political and moral interests, and are shaped in a cultural setting (Irvine, 1989). Scholars have outlined the ways in which language ideologies are created, sustained and ultimately abandoned in favour of alternative ideologies. Wee (2006), for instance, explored the interaction between language ideology and official language policy in the Singapore context, and showed how certain beliefs, rationalisations, and conceptions of language use have been instantiated, mediated, and altered by a range of governmental practices. 


\section{Islamic Religious Education}

Singapore is a secular state. With the exception of about 400 Malay/Muslim children who enrol in one of the six full-time Islamic religious schools (madrasah) each year, all other children attend the government-regulated national schools where religion and religious subjects have no place in the curriculum. Those who attend these national schools receive religious instructions either at home or in part-time religious education classes (Mukhlis Abu Bakar, 2009). The Islamic Religious Council of Singapore (MUIS), a statutory body, is entrusted to look after the interests of the Muslim community including the full-time madrasah and the part-time religious classes in the mosques.

For some time, Islamic religious education in Singapore has been perceived to suffer from shortcomings - over-emphasis on the cognitive skills of memorisation and rote learning, and attention to rituals. Such emphases appear to depart from ideas on education in contemporary society (Noor Aisha Abdul Rahman, 2006). In 2004, armed with the objective of making Muslims in Singapore remain rooted in their Islamic traditions yet well-adjusted to living in a modern society, MUIS introduced a new system of religious education in the mosques that develops students "intellectually, spiritually and emotionally into a responsible social being" (Youth Education Strategic Unit, 2007). Called the Singapore Islamic Education System but popularly known as aL.I.V.E. ('Learning Islamic Values Everyday'), it comprises a series of programmes targeted at different age groups - Kids aL.I.V.E. (for children aged 5-8 years old), Tweens aL.I.V.E. (9-12 year olds), Teens aL.I.V.E. (13-16 year olds) and Youth aL.I.V.E. (17-24 year olds). Offered on weekends in the mosques for an average of three hours per week, these programmes exist alongside the more traditional mosque madrasah programme which is to be gradually phased out and replaced by aL.I.V.E.

The change in curriculum and pedagogy extends to the medium of instruction, from Malay to English, to cater to Malay children who prefer English and to accommodate non-Malay-speaking Muslim students. This is a departure from the traditional practice of using Malay and Arabic as mediums of instruction in religious classrooms. Other than aL.I.V.E. and mosque madrasah programmes (both run by MUIS), there are other Islamic religious education classes (mostly in Malay) provided by community organisations such as Andalus, Pergas and Jamiyah. Prior to aL.I.V.E., the best known English-medium classes are those run for adult learners by the Muslim Converts' Association of Singapore.

This paper draws data from a study on children attending the Kids aL.I.V.E. (KA henceforth) and the mosque madrasah (MM henceforth). While the full study was on the impact of the programmes on their respective students and the parents' evaluation of the programmes, this paper focuses on a component of the study that looks at the issues around language from the parents' perspective. As stated previously, the study examined parents' language preferences in their children's learning of Islam and the ideologies behind those preferences. It also investigated language use in the KA and MM children's homes, and parents' assessment of their children's language proficiency. 


\section{Methodology}

\section{Participants}

Three mosques which offered the KA programme and another two which run the MM programme were selected for the study. The participants, all 8 years old, were randomly selected from the cohort of children in the final year (Year 4) of KA and in Year 2 of MM. The selection process entailed the supervisors of the respective mosques telephoning parents in alphabetical order from the class lists (ComptonLilly, 2003). The first 10 girls and 10 boys from KA whose families agreed to participate, were chosen for the study. Similarly, 10 girls and 10 boys from MM participated in the study. Five of the 20 children from the KA group were non-Malays and were not included in the analysis for this paper.

\section{Data Collection}

Following a pilot study, data from the 35 participants described above were collected over a period of four months. For each of the 35 children, one visit was made to the home lasting about two hours. The parents understood the visit as a means to gather feedback from them and their focal child about the programme. The researcher carried out face-to-face interviews with the parent(s) in attendance while a Research Assistant (RA) spent time with the focal child chatting up with him/her on some relevant topics. The data which this paper draws on are based on the interview with the parents (see Mukhlis Abu Bakar, 2012, for the report on the interview with the children).

The interview was conducted as the parents answered a questionnaire which consisted of 41 questions most of which were multiple choice questions. Some questions asked for additional comments with the possibility of more than one comment (open questions). The questions covered issues such as language use, attitude on education, curriculum appropriateness, children's learning, and parental engagement. Data for this paper are limited to questions on language use, language proficiency, and attitudes towards the instructional language of the programmes. All interviews were audio recorded.

During the interview, both parents could be present but one would be the primary respondent who was allowed to confer with his/her spouse for the latter's input such as the language(s) in which they speak with each other. The respondents were given a copy of the questionnaire in a language they preferred (English or Malay). The researcher went through the questions with them, and where their comments were solicited, they expressed them orally. Occasionally, they would be asked for elaborations after they finished a question. For example, a KA parent might choose "Extremely supportive" to a question that asked respondents to rate their support for the use of English but choose "Supportive" to a similar question that quizzed their support for Malay had it been used. The researcher would then ask them the reasons for their choices. Oral explanations allowed for a freer flow of information and further probing than written (Fink, 2012). Parents expressed themselves in either English or Malay, or both. 


\section{Data Analysis}

Responses to the multiple choice questions in the questionnaire were subjected to a descriptive analysis where percentages were obtained for each scored item. The recorded interviews were transcribed by Malay-English bilingual transcribers, and from the close examination of the transcripts, the researcher analysed for expressions of beliefs or ideologies about English and Malay.

\section{Results}

\section{Language Use in Malay Homes}

All the families declared Malay as their MT. One KA family spoke only Malay at home; the others spoke English and Malay. For the MM families, all spoke English and Malay at home. For $60 \%$ of KA and MM families, English was reported to be the most frequently used language at home. A breakdown in the patterns of language use at home is shown in Table 1.

Table 1

Language use in the homes of KA and MM children

\begin{tabular}{|c|c|c|c|c|}
\hline \multirow[b]{2}{*}{$\begin{array}{l}\text { Percentage of } \\
\text { language use }\end{array}$} & \multicolumn{2}{|c|}{ KA } & \multicolumn{2}{|c|}{ MM } \\
\hline & $\begin{array}{l}\text { Malay or } \\
\text { more Malay } \\
\text { than English }\end{array}$ & $\begin{array}{l}\text { English or } \\
\text { more } \\
\text { English than } \\
\text { Malay }\end{array}$ & $\begin{array}{l}\text { Malay or } \\
\text { more Malay } \\
\text { than English }\end{array}$ & $\begin{array}{l}\text { English or } \\
\text { more } \\
\text { English than } \\
\text { Malay }\end{array}$ \\
\hline $\begin{array}{l}\text { Parents to each } \\
\text { other }\end{array}$ & 67 & 33 & 79* & $21^{*}$ \\
\hline $\begin{array}{l}\text { Parents speaking } \\
\text { to children }\end{array}$ & 40 & 60 & 20 & 80 \\
\hline $\begin{array}{l}\text { Children speaking } \\
\text { to parents }\end{array}$ & 50 & 50 & 30 & 70 \\
\hline $\begin{array}{l}\text { Siblings to each } \\
\text { other }\end{array}$ & $36^{+}$ & $64^{+}$ & 20 & 80 \\
\hline
\end{tabular}

* Discounting one family where the parents were divorced

+ Discounting one one-child family

\section{Parents to each other}

The majority of the parents preferred to use Malay (67\% KA; 79\% MM) when they spoke to each other. Two mothers explained their inclination towards Malay as follows (English translations in square brackets):

We have always been speaking our native language when we were courting. Kalau cakap dengan my husband [If I speak with my husband] ..., I mean 
naturally mesti bahasa Melayu [it must be Malay]. Bila [when] in the company of our kids, kita terus macam [we'll make a] 180 degree change. Yah, so kalau ada kids [So, with the kids], mixture English and Melayu, but with my husband, Melayu aja lah! [only Malay!] (Mother of KA7)

I prefer Malay pasal Bahasa Melayu ni dia kira indah. Ada tata susilah dia. [I prefer Malay because it is aesthetically pleasing. There is moral order.] (Mother of KA9)

\section{Parents to children}

The linguistic scenery changes when children are factored in. The majority of parents were found to use more English than Malay when initiating talk with their children. This was especially seen with $\mathrm{MM}$ parents who were far more inclined to using English with their children (80\%) compared to KA parents (60\%). One mother admitted to using English as a matter of course and one father saw the need to expose his children to English:

I'm quite used to it so automatically we just converse in English ah. That's why. (Mother of MM7)

It's good to talk to them in English so that they are very fluent in English ah. Because I've experienced my first two... when we talked to them in Malay. So hopefully by talking to them (younger children) in English... especially those that when, the understanding of the concept. (Father of KA18)

\section{Children to parents}

The preference to use English extends to situations when children initiated talk with their parents. Comparing this with the preceding data on the languages parents spoke with their children, we see that more parents than children used English to initiate talk with the other. For MM, $80 \%$ of the parents chose English to speak to their children while $70 \%$ of their children used English to speak to their parents. For KA, $60 \%$ of the parents chose English to speak to their children while $50 \%$ of their children used English to speak to their parents.

\section{Siblings to each other}

The clearest trend of using more English can be seen when children speak to each other. Again, overall, parental reports show greater prominence among MM children $(80 \%)$ to use English than among KA children (64\%). 


\section{English and Malay Language Proficiency}

The parents were asked to rate their children's proficiency levels for the two languages they spoke on a scale of 1 to 4 with a rating of 1 being "poor" and 4 being "very good" (Table 2).

Table 2

Mean ratings of language proficiency of child respondents

\begin{tabular}{lcc}
\hline Mean ratings & Malay & English \\
\hline KA & 2.7 & 2.7 \\
MM & 3.1 & 3.3 \\
\hline
\end{tabular}

Parental reports of the mean ratings for Malay and English were both 2.7 for KA children, while for MM children the mean ratings were 3.3 for English and 3.1 for Malay. This indicates roughly equal proficiency in the two languages for both KA and MM children. Overall, MM children appeared to be bilingually more proficient than KA children given the former's higher scores for both languages.

\section{Reasons for selecting a programme}

Parents responded to a question on why they enrolled their children in the respective programmes. Their single or multiple answers were grouped in nine categories as shown in Table 3.

Table 3

Reasons for enrolling children in the respective programmes

\begin{tabular}{lcc}
\hline $\begin{array}{l}\text { 32. What made you decide to put your child in the } \\
\text { programme? }\end{array}$ & $\begin{array}{c}\mathrm{KA} \\
\text { (\% of total) }\end{array}$ & $\begin{array}{c}\mathrm{MM} \\
\text { (\% of total) }\end{array}$ \\
\hline It is conducted in English (for KA, and Malay for & $6(19)$ & $7(26)$ \\
MM) & $5(16)$ & $4(15)$ \\
It has a good curriculum and pedagogy & $5(16)$ & $5(18)$ \\
It is held in the mosque & $3(9)$ & $4(15)$ \\
The venue is conveniently located & $3(9)$ & - \\
It has no examination & $2(6)$ & $1(4)$ \\
It is run by MUIS & $2(6)$ & $3(11)$ \\
The time is convenient for the family & $2(6)$ & - \\
It is not stressful/has a relax environment & $4(13)$ & $3(11)$ \\
Miscellaneous reasons & &
\end{tabular}

The parents' reasons were mixed. Language was the most cited reason but it did not stand out. However, language was a weaker reason for KA parents than for MM parents (19\% and $26 \%$ respectively). This suggests that KA parents might not be as fixed on English as the medium of instruction than MM parents were on Malay. 


\section{Support for the language of instruction}

Parents were quizzed specifically on their support for the instructional language of the respective programmes. Table 4 shows the pattern.

Table 4

Extent of support for English or Malay as a medium of instruction

\begin{tabular}{ccccccc}
\hline \multicolumn{1}{c}{ English } & \multicolumn{3}{c}{ Malay } \\
\hline $\begin{array}{c}\text { Percentage } \\
\text { of } \\
\text { respondents }\end{array}$ & $\begin{array}{c}\text { Extremely } \\
\text { or very } \\
\text { supportive }\end{array}$ & Supportive & $\begin{array}{c}\text { Not } \\
\text { supportive }\end{array}$ & $\begin{array}{c}\text { Extremely } \\
\text { or very } \\
\text { supportive }\end{array}$ & Supportive & $\begin{array}{c}\text { Not } \\
\text { supportive }\end{array}$ \\
\hline KA & $\mathbf{8 5}$ & 15 & 0 & $\mathbf{5 0}$ & 30 & 20 \\
MM & $\mathbf{1 0}$ & 60 & 30 & $\mathbf{9 0}$ & 10 & 0 \\
\hline
\end{tabular}

For English, the number of parents who were "Very Supportive" or "Extremely Supportive" of the use of the language is high among KA parents (85\%) but very low among MM parents (10\%). In contrast, $90 \%$ of MM parents were "Very Supportive" or "Extremely Supportive" of the use of Malay in the programme with some $50 \%$ of KA parents also at least "Very Supportive" if Malay was used instead. There is therefore a 75 percentage point difference in extensive support for English between $\mathrm{KA}$ and $\mathrm{MM}$ parents in contrast to only 40 percentage point difference in extensive support for Malay between these two groups. In other words, KA parents were more supportive of Malay than MM parents were supportive of English, and that Malay was not too far behind English as the preferred medium to deliver the KA curriculum as far as KA parents were concerned. It is possible that they could still be drawn to the programme if the curriculum was delivered in Malay.

\section{Ideological Underpinnings of Language Choice}

Some of the mainstream discourses on language were evident in the way the parents expressed their support for the respective languages:

\section{English as the premium language for learning}

For KA parents, particularly those whose dominant household language was English, using English as a medium of instruction in KA fulfilled a practical purpose they as parents were comfortable helping their children learn through the language.

It meets our needs. (Mother of KA2)

... pasal kat sekolah biasa belajar bahasa inggeris kan? Jadi kalau ini pun bahasa Inggeris, OK jugak lah. [... in school they are used to learning English.

So continuing it here (in KA) is fine] (Father of FC12) 
Yes, it's good. In fact, when I get them Islamic books, macam [like] 'My Qur'an Friends' books ... it's all in English ... when they go to the bookstore, they will go to the English section first. (Mother of KA20)

\section{Both English and MT are equally important}

Some KA parents were not adverse to the idea of using Malay in the programme and were neutral with respect to which language was the medium of instruction:

Neutral (about which language to use), as long as he can understand what he is learning, I am very happy already. I tak ada [don't have] particular, (that) you must say in Malay. Kadang-kadang, kita orang manusia, kita boleh grasp in different language. [Sometimes, we human beings can grasp different languages.] (Mother of KA6)

Actually, urm, language, I have no issue lah, frankly speaking. The most important thing is the subject, the structure that they ... deliver to our children. I mean, if they understand, they know the values, ah, I'm okay with it lah you know. (Mother of KA18)

Some parents wanted their children to be exposed to their weaker language (English for KA, Malay for MM) by enrolling them in the programme where their weaker language is the medium of instruction:

I notice my number three (focal child), struggle a little bit more at madrasah (because of Malay). But I welcome that struggle because I want her (to) balance (in the use of English and Malay). (Mother of MM9)

\section{Malay as a marker of identity}

Some parents had an affinity towards Malay as a signature of their identity. For some MM parents, they rated their children's proficiency higher in English than in Malay and supported English more than Malay as the medium of instruction. Yet, they were acceptable to the existing arrangement of using primarily Malay, with English being used whenever the students had difficulty understanding:

You know ... because kalau [if] we don't support the use of Malay pun [also] very difficult ... yeah ... the best is of course is what they are currently doing now when I spoke to the Ustazah she said it's in Malay but she tries whenever the kids don't understand she will ... use some terms or phrases in English ... kalau [if] the child looks very blur or don't understand ... (Mother of $\mathrm{MM} 2$ )

... but we still want Malay to be used even though the child learns better in English ... (Mother of MM1) 
Some KA parents too preferred Malay over English:

... would rather Kids aL.I.VE. dalam bahasa Melayu supaya dia dapat belajar bahasa Melayu lebih lagi ... [in Malay so that he can learn more Malay]. (Father of KA12)

\section{Malay as the language of religion}

Some parents, KA and MM alike, insisted on using Malay to teach Islam as they were used to using the language in the religious domain:

I don't like them (KA) teaching them (children) in English. I rather that Islam teach in Malay. For me, kalau ugama, I lebih fasih cakap Melayu dari cakap English. [if religion, I am more proficient in Malay than in English] (Mother of $\mathrm{MM} 3$ )

Ah.. mama suggestlah mintak bahasa Melayu [ask for Malay] (mimicking a child's voice) .... Segi agama tu English tu pada dia susahlah. Lebih kepada Melayu ah. [For religion, it is hard for her if it's in English. She's more inclined towards Malay.] (Mother of KA16)

\section{English as the language of the young generation}

Some KA parents found it difficult to help their children's learning through English as they were not proficient in the language. As much as they thought that they understood better in Malay and felt that the use of Malay was more "mesra" (intimate), they accepted that their children's generation was different:

Untuk anak zaman sekarang kan bahasa Inggeris. Sekolah bahasa Inggeris, jadi pada saya pun takde masalahnya dalam bahasa Inggeris. [For today's generation, it's English. School is also in English, so I have no problem if (KA) also uses English] (Mother of KA4)

Lebih mudah ... kalau nak terangkan bahasa orang putih ..., kalau macam bahasa asing gitu dorang paham lah ... Macam kita orang Islam bahasa Melayu kita gunakan, jadi bila terjemahkan bahasa Inggeris susah kita nak tangkap. [It's easier for the younger generation to understand English. For us older generation who grew up with Malay, if something is in English, it is difficult to grasp.] (Mother of KA16)

... memang [it's true] mother tongue is important. It's the language for us eh, Melayu eh, tetapi dalam masa yang sama [but at the same time], most of the time diorang [they] (the children) dah gunakan bahasa Inggeris, ... lebih exposed dengan Bahasa Inggeris [have used, and are more exposed to, English]. That means, about dakwah [propagating religion], kalau diorang boleh exposed (to English), even their kawan-kawan diorang yang bukan 
dari agama Islam, boleh tertarik [if they are exposed to English, even their non-Muslim friends might be attracted]. (Mother of KA9)

\section{Discussion and Conclusion}

The findings show that English was the more dominant language at home for all the participants. With the exception of inter-spousal talk, interactions that involved children generally involved more English. This supports Cavallaro and Serwe's (2010) observations that young Malays in Singapore speak a notable amount of English. What is significant about this study, however, is the finding that students who used more English at home were the ones more likely to learn Islam through the medium of Malay. This speaks volumes about Malay language maintenance for which MM parents were active agents. Torn between pragmatism and ethnic sentiments, some sent their children to a Malay-medium religious education despite believing that the children learned better through English just so that the latter would not lose the ability to speak Malay:

I know ... it's so contradicting because at number 33 (question in the survey form), I say ... we say ' $\mathrm{No}^{\prime}$ (to a statement that the child learns better in Malay), ... but then we still want Malay to be used even though the child learns better in English. (Mother of an MM child)

MM parents had responded to the call to use more English at home to the point that their children became more comfortable with, and proficient in, the language and thus in a better position to negotiate the school curriculum. Yet these parents had not lost their cultural affinity to Malay. Enrolling their children in the MM programme was evident of their efforts to ensure that the children remained active users of the language so that it was not lost on them. The children's proficiency in both English and Malay shows that gains in the dominant language had not come at the expense of proficiency in the minority language. But it remains to be seen if such efforts are sustainable in the long run given the unceasing influence of English in the larger society spurred on in part by an English immersion education and the globalisation of English.

Malay language maintenance is currently a viable prospect also because the older members of the families (in this study, parents) actively spoke Malay to each other. This helped the young build a sense of language inheritance for Malay. It will be harder to maintain the language once this older generation of Malay speakers dies out. The young will find less need to speak exclusively in Malay or code-switch to Malay, and will have less opportunity even to be passive learners of Malay. It will be left to the school and perhaps the media to take on the challenging task of nurturing their linguistic heritage. For the present, there are still many Malay speakers in the community, and if appropriate steps are taken, the shift to English can be slowed, if not arrested, and a more stable form of bilingualism be achieved.

The findings in Tables 3 and 4 appear to make a case for a KA programme in Malay besides English. This is in view of the strong support given by KA parents for a Malay-medium programme had there been one. This is the group MUIS had won 
over, attracted by aL.I.V.E.'s modern, age-appropriate curriculum and pedagogy. MM parents too could be won over, especially those who wanted Malay to remain as the language of religious instruction. While the impending closure of the Malaymedium MM will not put an end to religious education in Malay as there are other providers other than MUIS, it does mean that the space for Malay will shrink, weakening its position as the mainstay for the maintenance of the language. Moreover, replacing the traditional Malay MM with the modern English KA will reinforce the association of English with modernity and the "new" while Malay with tradition and the "old". This modern-English and traditional-Malay bifurcation, though unintended, might only harm the status and vitality of the Malay language.

Parents worry that interacting with their young children in Malay would mean less opportunity for the children to develop English skills in time to negotiate the primary school curriculum which is entirely in English except for the learning of Malay. Parents might be persuaded to recalibrate their linguistic priorities, including their children's part-time religious instruction, if schools send concrete signals by according greater currency to the MT. This could mean implementing some contentarea instruction through the medium of MT from the start of schooling. As Oller and Eilers' (2002) study cited earlier has suggested, in settings where English is socially dominant, teaching content-area subjects through both English and MT would not lead to a lowering of children's English proficiency.

Scholars and academics have the duty to provide both the Malay community and the schools with alternative ideologies with regards to bilingualism. Current mainstream discourses assume cognitive separation of the linguistic systems in bilinguals which underpin much of Singapore's language-in-education policies. This is reflected in the allocation of different roles to English and the MTs and the employment of teaching methods, tools, resources and assessments that are grounded on mono-literacy. The beliefs that influenced KA and MM parents' decisions on which religious classes to send their children to all involved rationalisations couched in monolingual terms. With schools persisting on a monolingual approach in a "bilingual" system and presenting it as "neutral", it is not surprising that these parents remained lodged in this mode of thinking.

In conclusion, this study has established the extent to which Malay language maintenance in the religious domain is a viable endeavour. Ideologies play an important role in influencing parents' linguistic decisions in and outside the religious domain, and in turn their children's affiliation to the Malay language. It might be useful to revisit the beliefs that shape Singapore's English-plus-MT policy which, while crucial in establishing a citizenry that is able to connect with the Englishspeaking world thus giving Singapore its competitive edge, has the unintended consequences of pushing Malay out of many domains of language use including religion.

It must be emphasised, at this point, that all the data presented in this paper are from parental reports. While this is good for making inferences about language ideologies of the parents from questions about their language choice, preference and everyday use, it may not provide an accurate measure of the children's language proficiencies. Nevertheless, it is hoped that this study constitutes a key milestone in the study of Malay language maintenance in the religious domain. This study, even if 
not all-encompassing, hopefully has provided some observations and insights on the community's affiliations with Malay in comparison to English.

\section{Acknowledgement}

My sincerest gratitude to MUIS and the participating mosques for allowing me access to the students and their parents. I am especially grateful to the parents for welcoming me to their homes and giving me their precious time. I would like to thank Courtney Cazden, Shanthi Nadarajan and an anonymous reviewer for their helpful comments on drafts of this paper. All remaining errors are mine. This research project is contracted by MUIS. The views expressed in this paper do not necessarily represent the views of MUIS.

\section{Endnotes}

${ }^{1}$ In the majority of cases, the Malay community's assigned MT (Malay) is the children's first language (L1) learned from infancy. This is not necessarily the case for the Chinese and Indian communities. Their assigned official MT may not be their bonafide MTs. For instance, if a Chinese family speaks Hokkien as L1, the children still have to study Mandarin as a MT in school.

\section{References}

Cavallaro, F., \& Serwe, S. K. (2010). Language use and language shift among the Malays in Singapore. Applied Linguistics Review, 1(1), 129-170.

Chong, E. L. J., \& Seilhamer, M. F. (2014). Young people, Malay and English in multilingual Singapore. World Englishes, 33(3), 363-377.

Compton-Lilly, C. (2003). Reading families: The literate lives of urban children. New York: Teachers College Press.

Cummins, J. (1984). Bilingualism and special education: Issues in assessment and pedagogy. Clevedon: Multilingual Matters.

Cummins, J. (1991) Interdependence of first and second language proficiency in bilingual children. In E. Bialystok (Ed.), Language processing in bilingual children (pp. 70-89) Cambridge: Cambridge University Press.

Dixon, L. Q. (2011). The role of home and school factors in predicting English vocabulary among bilingual kindergarten children in Singapore. Applied Psycholinguistics, 32(1), 141-168.

Education is the road to success (1982, May 29). The Straits Times, p. 16.

Fink, A. (2012). How to conduct surveys: A step-by-step guide. Thousand Oaks, CA: Sage Publications.

Grillo, R. D. (1989). Dominant languages: Language and hierarchy in Britain and France. Cambridge: Cambridge University Press.

Irvine, J. T. 1989. When talk isn't cheap: Language and political economy. American Ethnologist, 16, 248-267.

Kwan-Terry, A. (2000). Language shift, mother tongue and identity in Singapore. International Journal of the Sociology of Language, 143, 85-106. 
Kuo, E. C. Y. (1980). The sociolinguistic situation in Singapore: Unity in diversity. In E. A. Afendras \& E. C. Y. Kuo (Eds.), Language and society in Singapore (pp. 39-62). Singapore: Singapore University Press.

Kuo, E. C. Y., \& Jernudd, B. H. (2003). Balancing macro and micro sociolinguistic perspectives in language management: The case of Singapore. In J. Lindsay \& Y. Y. Tan (Eds.), Babel or Behemoth: Language trends in Asia (pp. 103-124). Singapore: Asia Research Institute, National University of Singapore.

Lanauze, M., \& Snow, C. E. (1989). The relation between first- and second-language writing skills: Evidence from Puerto Rican elementary school children in bilingual programs. Linguistics and Education, 1, 323-340.

Ministry of Education (2010). Nurturing active learners and proficient users. 2010 Mother Tongue Languages Review Committee Report. Ministry of Education, Singapore

Mukhlis Abu Bakar (2009). Islamic religious education and Muslim religiosity in Singapore. In J. A. Banks (Ed.), The Routledge international companion to multicultural education (pp. 437-448). New York: Routledge.

Mukhlis Abu Bakar (2012). Learning and spirituality in young Muslim children. Journal of Religious Education, 60(3), 25-34.

Noor Aisha Abdul Rahman. (2006). The aims of madrasah education in Singapore: Problems and perceptions. In N. A. Abdul Rahman, \& A. E. Lai (Eds.), Secularism and spirituality: Seeking integrated knowledge and success in madrasah education in Singapore (pp. 58-92). Singapore: Singapore Institute of Policy Studies \& Marshall Cavendish Academic.

Norhaida Aman. (2009). The linguistic practices of bilingual Singapore Malay students: A tale of language maintenance. Jurnal e-Utama, 2(1), 47-68.

Oller, D. K., \& Eilers, R. E. (Eds.). (2002). Language and literacy in bilingual children. Clevedon: Multilingual Matters.

Ong, S. C. (2006, Aug 19). Who are you? Where do you live? The Straits Times, p. S10.

Rohan Nizam Basheer. (2008). Peralihan bahasa Melayu dalam domain agama: Satu kajian kes di Singapura [Malay language shift in the religious domain: a case study in Singapore]. Unpublished MA thesis, University of Malaya, Malaysia.

Roksana Bibi Abdullah (2003). Bahasa Melayu di Singapura: Pengalihan dan pengekalan [The Malay Language in Singapore: Shift and maintenance]. Singapore: DeeZed Consultant.

Sa'eda Buang. (2010). Muslim education and globalization: The re-(de)positioning of languages and curriculum content in Southeast Asia. In V. Vaish (Ed.), Globalization of language and culture in Asia: The impact of globalization processes on language (pp. 34-60). London \& New York: Bloomsbury Publishing.

Schiffman, H. F. (2002). Tongue tied in Singapore: A language policy of Tamil? Journal of Language, Identity and Education, 2(2), 105-125.

Singapore Department of Statistics (2001). Census of population 2000 statistical release 2: Education, language and religion. Singapore: Department of Statistics, Ministry of Trade \& Industry, Republic of Singapore.

Singapore Department of Statistics (2011). Census of population 2010 statistical release 1: Demographic characteristics, education, language and religion. 
Singapore: Department of Statistics, Ministry of Trade \& Industry, Republic of Singapore.

Stroud, C. (2007). Multilingualism in ex-colonial countries. In P. Auer \& W. Li (Eds.) Handbook of multilingualism and multicultural communication (pp. 509537). Berlin \& New York: Mouton de Gruyter.

Vaish, V. (2008). Mother tongues, English, and religion in Singapore. World Englishes, 27(3-4), 450-464.

Wee, L. (2006). The semiotics of language ideologies in Singapore. Journal of Sociolinguistics, 10, 344-361.

Wee, L. (2011). Language policy mistakes in Singapore: Governance, expertise and the deliberation of language ideologies. International Journal of Applied Linguistics, 21(2), 202-221.

$\mathrm{Xu}, \mathrm{D} ., \mathrm{Cheng,} \mathrm{H.} \mathrm{C.,} \mathrm{\&} \mathrm{Chen,} \mathrm{S.} \mathrm{(1998).} \mathrm{Language} \mathrm{use} \mathrm{and} \mathrm{language} \mathrm{attitudes} \mathrm{in} \mathrm{the}$ Singapore Chinese community. In S. Gopinathan, A. Pakir, Ho W. K. \& V. Saravanan (Eds.), Language, Society and Education in Singapore (pp. 133155). Singapore: Times Academic Press.

Youth Education Strategic Unit (2007). Singapore Islamic Education System: A conceptual framework. Singapore: Islamic Religious Council of Singapore. 